\title{
AZ EGÉSZSÉGES TÁPLÁLKOZÁS SZEREPE ÉS JELENTÔSÉGE
}

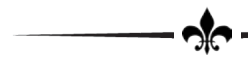

ROLE AND IMPORTANCE OF HEALTHY EATING

\author{
- \\ ${ }^{1}$ PFAU, Christa \\ ${ }^{1}$ MüLLER, Anetta \\ ${ }^{2} B A ́ C S$, Zoltán \\ ${ }^{1}$ BÁCSNÉ BÁBA, Éva
}

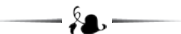

${ }^{1}$ Debreceni Egyetem, Gazdaságtudományi Kar, Vidékfejlesztés, Turizmus- és Sportmenedzsment Intézet

(University of Debrecen, Faculty of Economics and Business, Institute of Rural Development, Tourism and Sports Management) ${ }^{2}$ Debreceni Egyetem, Gazdaságtudományi Kar, Számviteli és Pénzügyi Intézet

(University of Debrecen, Faculty of Economics and Business, Institute of Accounting and Finance)

H-4032 Debrecen, Böszörményi út 138.

e-mail: pfau.christa@econ.unideb.hu

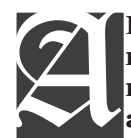

Healthy nutrition and a regular exercise are two important pillars of healthy lifestyle. Several researches point out that significant part of the population has incomplete knowledge regarding these topics. The Hungarian population is characterized by unhealthy eating habits and low level of regular exercise, which together result in a high obesity rate and poor health status among the Hungarians. Besides these, another unfavourable fact is the sedentary lifestyle: adults spend more than 5 hours a day in sitting position on average. The Hungarians' daily physical activity is only $70 \%$ of the recommendations, and we only spend 10 minutes a day doing sports. Vegetables and fruits are important ingredients of a healthy and balanced diet, the consumption rate of which is quite low in several European countries including Hungary. In our article we present the main characteristics and contexts of healthy nutrition and physical activity. In addition, we analyze a nutrition research activity which can be an important basis for integrative strategies. Based on secondary research, we present research results that demonstrate the protective effects of vegetable and fruit consumption connected to various diseases. Furthermore, we present the unfavorable tendencies of vegetable and fruit consumption of the European and Hungarian population, and we make suggestions in order to improve the unfavourable circumstances and indicators. We also focus on the socio-ecological model of the nutrition guideline, the levels of which significantly affect our habits related to nutrition and physical activity.

KuLCSSZAVAK: egészséges táplálkozás, fizikai aktivitás, védelmező faktor, gyümölcs- és zöldségfogyasztás

JEL-KóD (JEL CODE): I12

DOI: https://doi.org/10.20494/TM/5/1/4

\section{BEVEZETÉS - INTRODUCTION}

Az egészséges táplálkozás és a rendszeres testmozgás az egészséges életmód két kiemelten fontos pillére. Mindezek megvalósításához azonban elengedhetetlen, hogy megfelelő ismeretekkel rendelkezzen az egyén és a társadalom. Több kutatás is arra hívja fel a figyelmet,
KEYWORDS: healthy nutrition, physical activity, protective factor, fruit and vegetable consumption 
jellemző az ülő életmód, melyet azon tény igazol, hogy egy felnőtt átlagosan naponta több mint 5 órát tölt üléssel. A fizikai aktivitás alacsony szintjéről árulkodnak azok az adatok is, melyek szerint naponta csupán 7000 lépést teszünk meg, amely az ajánlás csupán 70\%-át jelenti, továbbá naponta mindösszesen 10 percet töltünk sportolással. A magyarok még mindig előnyben részesítik a magyar konyha tradicionális ételeit és ízeit. Étrendünkre jellemző a sok zsír (fóleg állati eredetű), a kevés rost, a túlzott sóbevitel és a kevés zöldség-, illetve gyümölcsbevitel. Az egészséges és kiegyensúlyozott étrend egyik fontos összetevője a zöldség és gyümölcs, melynek fogyasztása több európai országban, köztük Magyarországon is kedvezőtlenül alacsony szinten realizálódik (OTÁP, 2014).

\section{ANYAg ÉS MóDSZER - MATERIAL} AND METHOD

Kutatásunk során szekunder adatelemzést végeztünk, amelyben a KSH adatokat, OTÁP vizsgálatokat és a témával kapcsolatos releváns hazai és nemzetközi kutatások eredményeit elemeztük. Az amerikai lakosságnak készült és a WHO-s ajánlásokat használtunk fel a táplálkozás és rendszeres testmozgás összefüggéseinek bemutatására, mivel megállapításaik adaptálhatók és hasznosíthatók. Kiemelten foglalkozunk a táplálkozási útmutató társadalmi-ökológiai modelljével, melynek szintjei befolyásolják a táplálkozási és fizikai aktivitással kapcsolatos szokásainkat.

\section{EREDMÉNYEK - REsults}

\subsection{Az egészséges táplálkozás fogalmi összetevői és szociokulturális dimenziói - Conceptual Components and Socio-cultural Dimensions of Healthy Nutrition}

Az egészséges táplálkozás kialakításához a különféle élelmiszereket és folyadékokat megfelelő arányban, mennyiségben és változatosan kell fogyasztani. Az élelmiszer mennyiségét be- folyásolja a napi energiaszükséglet, amely függ a nemtől, az életkortól, az aktuális testtömegtôl, a sportolási szokásoktól és a napi fizikai tevékenységtől.

$\mathrm{Az}$ egészségkockázatokkal kapcsolatos tényezők vizsgálata alapján megállapítható, hogy a hazai egészségveszteségek kockázatai 80\%-ban viselkedéssel összefüggő tényezőkre vezethetők vissza. A legnagyobb hangsúlyt képviselők, úgymint az étrendi kockázatok, a dohányzás, az alkohol- és kábítószer-fogyasztás mellett kiemelt szerepet játszik az egyén egészségmagatartása is. Az egészségmagatartási mutatók Magyarországra vonatkozó értékei az EU-átlaghoz képest kirívóan rosszak (NEFI, 2016). Ezek a tények is alátámasztják, hogy elengedhetetlen a népegészségügyi tervezés során az egészségmagatartás megváltoztatására irányuló beavatkozások előtérbe helyezése. Hasonló következtetéseket tartalmaz az OECD kutatása, amely 35 ország adatait elemzi (OECD, 2017). Megállapítja, hogy az egészségügyi eredmények az egészségügyi rendszeren belüli és azon túlmenő beruházásoktól is függnek. Az egyén egészsége nemcsak a kapott orvosi ellátástól függ, hanem más tényezők is befolyásolják (KAPLAN, 2006). Az egészség szélesebb társadalmi determinánsai is számítanak (jövedelem, oktatás, munka és az életkörülmények). A megfelelő jövedelem lehetővé teszi az alapvető termékek és szolgáltatások vásárlását, amelyek fenntartják vagy javítják az egészséget, mint például a megfelelő mennyiségű és minőségű étel. Bár a magasabb jövedelem hosszabb munkaidőt és nagyobb stresszt is okozhat (FUCHS, 2004). A magasabb iskolai végzettségüek, akik általában nagyobb diszkrecionális jövedelemmel is rendelkeznek, tájékozottabbak az egészségmagatartás faktorairól (MACKENBACH et al., 2008; OECD, 2017).

A kockázatok rangsorában a legnagyobb egészségveszteséget a nőknél és a férfiaknál is ugyanazok a tényezők okozzák, melyeket három nagy csoportba lehet besorolni: (1) viselkedés okozta kockázatok (dohányzás, stressz, egészségtelen táplálkozás, mozgáshiányos életmód), (2) élettani kockázati tényezők (genetika), (3) környezeti kockázatok. A rangsorban csupán a túlzott alkoholfogyasztás és a magas sófogyasztás esetében figyelhető meg lényegesebb eltérés. Megállapítható, hogy egyetlen 
környezeti faktort (levegő porszennyezettsége) leszámítva valamennyi jelentős kockázat közvetlenül vagy közvetve a viselkedési kockázathoz, ezen belül is fóként a táplálkozási kockázati tényezőhöz kapcsolható (VITRAI, BAKACS és VARSÁNYI, 2017).

A táplálkozás az egészség megőrzésének legfontosabb tényezője (JOVIČIĆ, 2015). Az egészséges táplálkozás az egészség megőrzésének és az általános jó közérzet kialakításának egyik legfontosabb eszköze (NIVA, 2007). Az egészséges táplálkozás hozzájárul az általános jólléthez (SHEPHERD et al., 2006), és számos fontos krónikus betegség megelőzésének alapja (WHO/FAO, 2003). Az egészséges táplálkozás kiegyensúlyozott és változatos étrendet jelent, melynek jellemző összetevői a friss és természetes ételek, sok gyümölcs és zöldség, valamint vitaminokat és ásványi anyagokat tartalmazó élelmiszerek (POVEY et al., 1998). Ez magában foglalja az étkezési szokásokat és viselkedéseket is, amelyek összhangban állnak a fizikai és pszichológiai egészség javításával és/vagy fenntartásával (POLIVY és HERMAN, 2005).

Az egészséges és egészségtelen táplálkozást mind egyéni, mind kollektív (társadalmi és környezeti) tényezők befolyásolják (POLIVY és HERMAN, 2005; VARGA-HATOS és KARNER, 2008).

Az amerikai kormány 2008-ban elkészítette „A fizikai aktivitás irányelvei” című kiadványát, mely minden korosztálynak iránymutatást ad a megfelelő mennyiségű és típusú fizikai aktivitáshoz (PHYSICAL ACTIVITY GUIDELINES, 2008). Ajánlásai hasonlóak a WHO által készítettel (WHO, 2010). Ehhez hasonlóan táplálkozási útmutatót állítottak össze az amerikai szakemberek is, melynek tanácsai nélkülözhetetlenek az egészségügyi és a politikai döntéshozók számára, mivel ők tervezik és hajtják végre az élelmiszer- és táplálkozási programokat. Az élelmiszer, az egészségügy és az orvostudomány területéról felkért kutatók munkáját egy tudományos jelentésben foglalták össze, amely tanácsokat és ajánlásokat adott a szövetségi kormánynak a táplálkozással és az egészséggel kapcsolatban (DIETARY GUIDELINES, 2015). $\mathrm{Az}$ ajánlások végső soron az egészség megőrzését és fenntartását, valamint a krónikus betegségek kockázatának csökkentését célozzák.
Ezen elvek mentén valósul meg az Egyesült Államokban múködő USDA (United States Department of Agriculture) Nemzeti Iskolai Reggeli- és Ebédprogram, amelynek keretében összesen több mint 30 millió gyermeket táplálnak naponta. A táplálkozási irányelvek olyan információkat is szolgáltatnak, amelyek segítik az egészséges táplálkozási szokások kialakítását az egyén és családja számára is.

A fizikai aktivitással és az egészséges táplálkozással kapcsolatban készült útmutatók hatására olyan paradigmát lenne szükség kialakítani, amely alapján otthoni környezetben, az iskolában, a munkahelyen és a közösségben az egészséges életmód választása egyszerü, hozzáférhető, megfizethető és természetes lenne. Több tényezőnek szerepe van az egészséges táplálkozási minták létrehozásában és támogatásában.

A táplálkozási útmutató bemutat egy társadalmi-ökológiai modellt (1. ábra), melynek különböző szintjein végrehajtott változtatás javítaná a táplálkozási és a testmozgással kapcsolatos szokásainkat. Például az iskolai étkezési környezet javítását célzó politikák javítják a gyermekek étkezési magatartását, ami egészségesebb étkezést eredményez. A társadalmi-ökológiai modell összefoglalja, hogyan befolyásolják az ágazatok, a felhasználói környezet, a társadalmi és kulturális normák és az egyéni tényezők a táplálkozási és a fizikai aktivitási szokásokat (DIETARY GUIDELINES, 2015).

A társadalmi és kulturális normák olyan írt és íratlan szabályok, amelyek a táplálkozás és a testmozgás tekintetében például bizonyos típusú élelmiszerek preferenciáit, az elfogadható testtömeg-tartományokra vonatkozó attitűdöket és a fizikai aktivitással és egészséggel kapcsolatos értékeket jelentik. Mivel a normák és értékek egy közösségen vagy környezeten belül érvényesülnek, nehéz megváltoztatni őket. Azonban a különböző „szektorokban” és a felhasználói környezetben bekövetkező változások erőteljesen hatnak a társadalmi és kulturális normákra és értékekre, melyek összhangban állhatnak a táplálkozási irányelvekkel is.

A szektorok közé tartoznak a társadalmi alrendszerek (pl. kormányzat, oktatás, egészségügy és tömegközlekedés), a szervezetek (pl. közegészségügy, önkormányzat, érdekvé- 


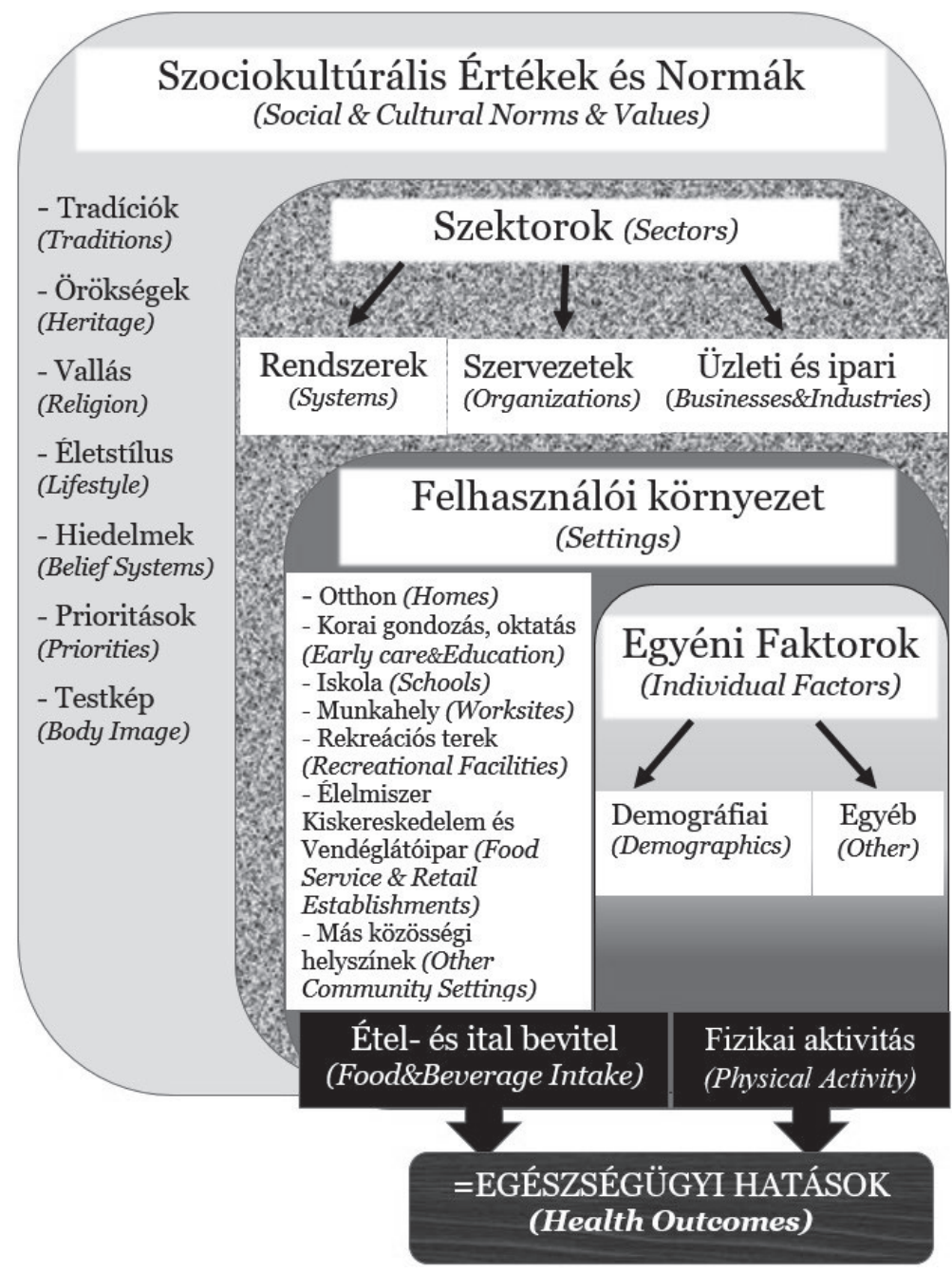

1. ÁBRA

A táplálkozásra és fizikai aktivitásra ható tényezők társadalmi-ökológiai modellje (Social-Ecological Model for Food and Physical Activity Decisions)

Forrás (Source): Saját szerkesztés a Dietary Guidelines, 2015 alapján (Own construction based on Dietary Guidelines, 2015)

delem, fogyasztóvédelem) és az üzlet- és iparágak (pl. tervezés és fejlesztés, mezőgazdaság, élelmiszer, kiskereskedelem, szórakoztatóipar, marketing és média). Ezek mind fontos szerepet játszanak abban, hogy segítsék az egyént az egészségével kapcsolatos döntések meghozatalában, mert vagy befolyásolják azt, hogy az ember milyen mértékben fér hozzá az egészséges táplálékhoz és/vagy a fizikai aktivitáshoz, vagy hatást gyakorolnak a társadalmi normákra és értékekre (DIETARY GUIDELINES, 2015).

Felhasználói környezetnek tekinthetjük az élet mindennapi színtereit, az otthonunkat, valamint a munka, az iskolai és mindennapi tevékenységeink helyszíneit (bölcsőde, óvoda, iskola, munkahely, rekreációs központok, élelmiszer-kiskereskedelmi és vendéglátó-ipari létesítmények). Ezek a helyszínek közvetlenül meghatározzák, hogy milyen élelmiszerek, ételek és fizikai aktivitási lehetőségek állnak ren- 
delkezésre. A közvetlen felhasználói környezetben megvalósított egészséges táplálkozási iránymutatásokra irányuló stratégiák befolyásolhatják az egyéni döntéseket, és szélesebb népegészségügyi hatással rendelkezhetnek, ha több ágazatra kiterjedő stratégiákkal integrálódnak.

Az egyéni faktorok közé tartozik az életkor, a nem, a társadalmi-gazdasági helyzet, a faj/ etnikum, a fogyatékosság jelenléte, valamint más hatások, mint például a fizikai egészség, a tudás és a készségek, valamint a személyes preferenciák, egyedi tényezők. Az amerikai lakosság számára készült fizikai aktivitás és táplálkozási irányelvek segítenek olyan programok és lehetőségek kidolgozásában, amelyek pozitívan hatnak az emberek táplálkozási és fizikai aktivitási szokásaira. A modell adaptálható országonként, de ennek során figyelembe kell venni az egyes területek társadalmi, kulturális értékei, szektorai, felhasználói környezete és az egyéni jellemzók közti különbségeket (DIETARY GUIDELINES, 2015).

\subsection{Kutatások az egészséges táplálkozás köréból - Research on Healthy Nutrition}

Az egészséget veszélyeztető kockázati tényezőket a viselkedés okozta kockázatok, az élettani kockázati tényezők, illetve a környezeti kockázatok alkotják. Hazánkban a magyar lakosság összes, kockázati tényezőhöz köthető egészségveszteségét vizsgálva a háromnegyede (76\%) az egészségkárosító viselkedéshez, 56\%a élettani kockázati tényezőkhöz és 16\%-a környezeti kockázathoz volt kapcsolható (VITRAI, BAKACS és VARSÁNYI, 2017).

Az étrendi kockázatok voltak okolhatók a felnőtt lakosság egészségveszteségének 16\%áért. Az étrendi kockázatok közül a teljes kiőrlésü gabonafélék elégtelen fogyasztása, a magas sóbevitel, a kevés zöldség- és gyümölcsfogyasztás, valamint az olajos magvak elégtelen bevitele okozta a legnagyobb veszteségeket (NEFI, 2016).

KISS és munkatársai (2016) hazai lakosság körében végzett fókuszcsoportos vizsgálatából kiderül, hogy valamennyi korcsoportra igaz az, hogy nem ismerik a funkcionális élelmiszerek fogalmát, mely jelzi a hiányos ismereteket az egészséges táplálkozással kapcsolatban. Ezt igazolja az Egyesült Államokban $(\mathrm{N}=1000)$ végzett reprezentatív kutatás is, ahol a megkérdezettek $47 \%$-a nem tudta azt az alapvetően fontos információt, hogy számára mennyi az ideális energiabevitel. Akik válaszoltak és megjelöltek egy energiaértéket, azok között csupán $20 \%$ volt, aki jó adatot jelölt meg. A válaszadók 94\%-a nyilatkozta, hogy figyeli az ételeken, élelmiszereken található címkét, azonban nem értik, mit látnak a csomagoláson (IFIC, 2007).

Bár sok kutatás bizonyítja, hogy a serdülőkorú gyerekek rendelkeznek az egészséges táplálkozással kapcsolatos elméleti ismeretekkel, azonban ez nem elégséges, mivel nehezen tudják ezt az elméleti tudást a gyakorlatba is átültetni (STORY, NEUMARK-SZTAINER és FRENCH, 2002; POPPER és KROLL, 2005).

Az egészséges táplálkozásban a zöldségeknek, gyümölcsöknek fontos szerepe van, egyrészt természetes vitaminforrások, másrészt biztosítják a szervezet mikro- és makro-anyag ellátását (RIGÓ, 2007; HENTER, MRAMURÁCZ és SZABÓ, 2013).

A gyümölcsök és zöldségek napi fogyasztása csökkentheti a koszorúér-betegségek, az agyvérzés és egyes rákos megbetegedések kockázatát (WORLD CANCER RESEARCH FUND, 2007; HARTLEY et al., 2013).

SZỨCS (2016) ismerteti az Okostányér megalkotásának elméleti alapjait, mely kialakítása során az amerikai mintát (ChooseMyPlate) alapul véve figyelembe vették a hazai adottságokat, gasztro-kulturális hagyományokat. A Magyar Dietetikusok Országos Szövetsége és a Magyar Tudományos Akadémia Élelmiszertudományi Tudományos Bizottsága ajánlásával készült el az Okostányér, melynek egyik érdeme, hogy a különböző élelmiszercsoportok rugalmas kombinációjával válik kézzelfoghatóvá a hétköznapok szintjén az egyéni igények, preferenciák, kulturális hagyományok figyelembevételével az egészséges táplálkozás. Az ajánlás többek között megfogalmazza a zöldségek és gyümölcsök fogyasztásának napi szükségességét. A mennyiségi előírásnak a napi minimum 4 adag zöldség vagy gyümölcs elfogyasztását ajánlja, melyből legalább 1 adag friss vagy nyers legyen. 


\subsection{A hazai és nemzetközi zöldség- és gyümölcsfogyasztás - National and International Vegetable and Fruit Consumption}

Világszerte a kevés gyümölcsfogyasztás 2015ben közel 3 millió, míg az alacsony zöldségfogyasztás közel 2 millió, az alacsony fizikai aktivitás pedig 1,6 millió ember halálát okozta (OECD, 2017). Az OECD adatai szerint a felnőttek 57 százaléka fogyaszt naponta gyümölcsöt (nemi bontásban a nők 63\%-a, míg a férfiak 50\%-a). Magyarországon (59,1\%) többen esznek gyümölcsöt, mint az OECD átlag (56,8\%). A legmagasabb arányt Ausztráliában (95\%) és Olaszországban (76,2\%), míg a legalacsonyabbat Finnországban (32,3\%) és Lettországban (29,7\%) tapasztalhatjuk. A zöldségfogyasztás hazánkban (46,3\%) elmarad az OECD átlaghoz (59,8\%) képest, de a miénknél is kevesebb ez az arány Németországban (34,1\%) és Hollandiában (29,4\%). A statisztikák alapján a 15 évesek több mint 40\%-a naponta fogyaszt gyümölcsöt Kanadában, Dániában és Svájcban, míg Görögországban és Svédországban kevesebb mint 25\%-a. Háromból egy gyermek fogyaszt naponta gyümölcsöt. A lányok több zöldséget és gyümölcsöt fogyasztanak, mint a fiúk, mely valamennyi vizsgált országra igaz. Összességében a napi zöldségfogyasztás OECD átlaga $32 \%$, közel azonos a gyümölcsfogyasztás átlagával, hazánkban ez átlag alatti, 25,5\% (OECD, 2017).

A gyümölcs- és zöldségfogyasztásra vonatkozó jelenlegi ajánlások szerint: legalább 400 g (Világ Rákkutató Alap, WHO, Anglia), de a skandináv államokban már 500-750 g és az USA-ban 640-800 g a napi ajánlott mennyiség (AUNE et al., 2017). A legáltalánosabban elfogadott irányelv szerint naponta legalább öt adag gyümölcsöt és zöldséget kellene fogyasztanunk (OECD, 2017). A mennyiség nagyjából megegyezik a hazai ajánlással, leginkább a fogyasztási alkalomban van eltérés.

A magyar felnőttek tápanyagbeviteli értékeit bemutató kutatások tapasztalatai is igazolják a kedvezőtlen táplálkozási szokásokat. Az állati eredetű zsiradékok, a húsok, húskészítmények rendszeres és túlzott fogyasztása, a zöldségek, gyümölcsök, a tej és tejtermékek, valamint a gabonafélék, különösen a teljes kiőrlésű gabonákból készült élelmiszerek igen alacsony fogyasztása és a magas kalóriabevitel jellemző táplálkozási szokásainkra (ERDEI et al., 2017; NAGY et al., 2017; SCHREIBERNÉ MOLNÁR et al., 2017). Az elérhető zöldségek és gyümölcsök régiónként, társadalmi-gazdasági szinten és szezononként is változnak.

2009-ben és 2014-ben végzett OTÁP felmérésben, mely a magyar lakosságra vonatkozó reprezentatív kutatás eredményeit közli (SCHREIBERNÉ MOLNÁR et al., 2017), olvasható a friss zöldség- és gyümölcsfogyasztással kapcsolatban az a negatív tendencia, miszerint ezen termékek fogyasztása 2009-hez képest csaknem ötödével csökkent. A gyümölcs és zöldségfogyasztás alakulását 2010 és 2016 között a 2. ábra szemlélteti (KSH, 2017).

2. ÁBRA

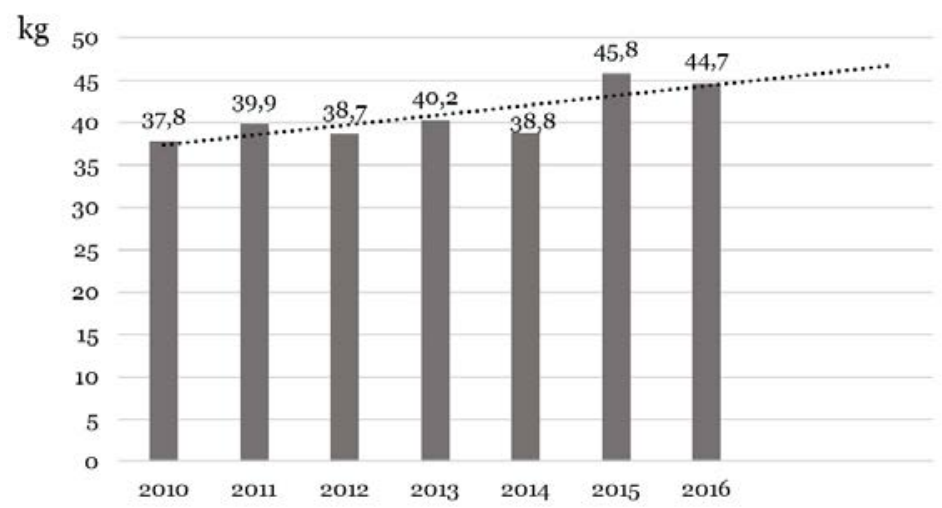

Egy fớre jutó hazai éves gyümölcsfogyasztás, 2010-2016

FIG. 2

\section{(Annual Fruit Consumption Per Capita in Hungary, 2010-2016)}

Forrás (Source): Saját szerkesztés KSH, 2017 alapján (Own construction based on KSH, 2017) 
Az ábra jól illusztrálja, hogy az egy főre eső gyümölcsfogyasztás mennyisége 2001-et alapul véve 2016-ra növekedett, 2016-ban azonban kevesebb gyümölcsfogyasztást tapasztalhattunk, mint 2015-ben, melynek oka minden bizonnyal a gyümölcsök áremelkedése volt. A gyümölcsfogyasztás lineáris előrejelzési trendje a jövőben lassú fogyasztásbővülést prognosz- tizál. Mivel a gyümölcsfogyasztást az ár illetve a lakosság jövedelmének alakulása igen erősen befolyásolja, így az árpolitika alakításával jelentős mértékủ javulást lehet elérni a lakossági gyümölcsfogyasztásban.

A 3. ábrán a hazai lakosság zöldségfogyasztásának alakulását láthatjuk 2010- 2016 között.

\section{3. ÁBRA}

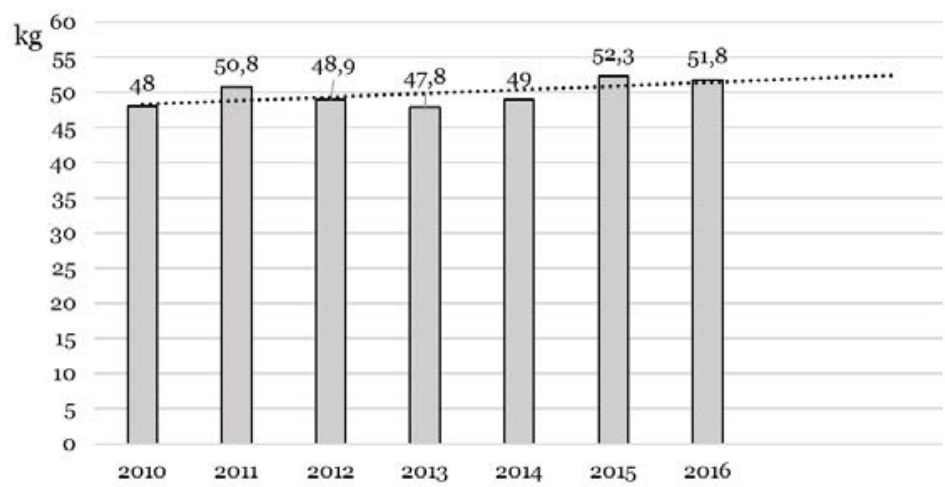

Egy főre jutó hazai éves zöldségfogyasztás (burgonya nélkül) 2010-2016, kg

(Per Capita Consumption of Vegetable (Without Potatoe) in Hungary, 2010-2016, kg)

Forrás (Source): Saját szerkesztés KSH, 2017 alapján (Own construction based on KSH, 2017)

Megállapítható, hogy a zöldségfogyasztás is mérsékelt növekedést mutat a vizsgált 6 év viszonylatában. Itt is hasonló tendencia érvényesül, mint a gyümölcsfogyasztás esetében, azaz 2016-ban kevesebb zöldségfogyasztás realizálódott 2015-höz képest, melynek oka ugyancsak a fogyasztói árak emelkedésében keresendő. Az adatok szerint a felnőttek kétharmada nem fogyasztott az ajánlásoknak megfelelő mennyiségü zöldséget, gyümölcsöt.

A zöldség és gyümölcs fogyasztásának protektív hatását már bizonyították (ROBERTSON et al., 2004). A szív- és érrendszeri betegségek és a daganatos megbetegedések a vezető halálokok között szerepelnek nem csak hazánkban, de a legtöbb iparosodott országban is. A zöldségek-gyümölcsök rendszeres fogyasztása együtt jár a daganatos (DRAGSTED, STRUBE és LARSEN, 1993; BOYLE et al., 2000; LE MARCHAND et al., 2000), a szív- és érrendszeri betegségek (ARAI et al., 2000; JOSHIPURA et al., 2001), a stroke, az Alzheimer-kór, szürke hályog valamint néhány más, az öregedéssel kapcsolatos betegség rizikójának csökkenésével (LIU, 2003).
A táplálkozás fontosságának egészséggazdasági megközelítése szerint Európában a betegségek általános terhének 4,4\%-a az alacsony gyümölcs- és zöldségfogyasztásnak tulajdonítható (WHO, 2002).

Ha megvizsgáljuk Európa gyümölcsfogyasztását, látható, hogy Románia (28,8\%) rendelkezik a napi gyümölcsbevitel legalacsonyabb értékével, majd utána Bulgária $(35,4)$ és Lettország (39,8\%) következik (1. kép).

Hazánk esetében átlag feletti gyümölcsbeviteli adatokat tapasztalhatunk (59,2\%). Legnagyobb százalékban a spanyolok (66,7\%), a portugálok (70,9\%), az olaszok (70,9\%) esznek naponta legalább egyszer gyümölcsöt. Ezt magyarázhatja, hogy a mediterrán konyha elengedhetetlen eleme a sok zöldség és gyümölcs. A mediterrán országok magas gyümölcs- és zöldségfogyasztásának megvannak a kulináris hagyományai, hiszen az úgynevezett mediterrán konyha elemei között szerepel az olívaolaj, a fehér húsok, a teljes kiőrlésű gabonafélék és a zöldségek-gyümölcsök domináns használata (DERNINI és BERRY, 2015).

A napi zöldségfogyasztás százalékos ered- 
ményeit láthatjuk a 2. képen. A gyümölcsbevitellel azonosan, Románia (29,6\%) zöldségfogyasztása a legkedvezőtlenebb az Európai Unióban.

Meglepő módon a hollandok 31,3\%-a és a németek 34,1\%-a eszik naponta legalább egyszer zöldséget, mely az átlaghoz (50,1\%) képest alacsonynak számít. A legmagasabb zöldségfelhasználás a belgákat $(78,5 \%)$ és az angolokat $(65,5 \%)$ jellemzi.

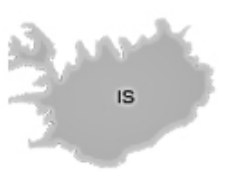

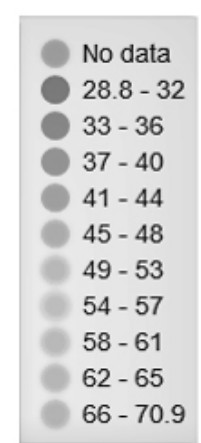

1. KÉP

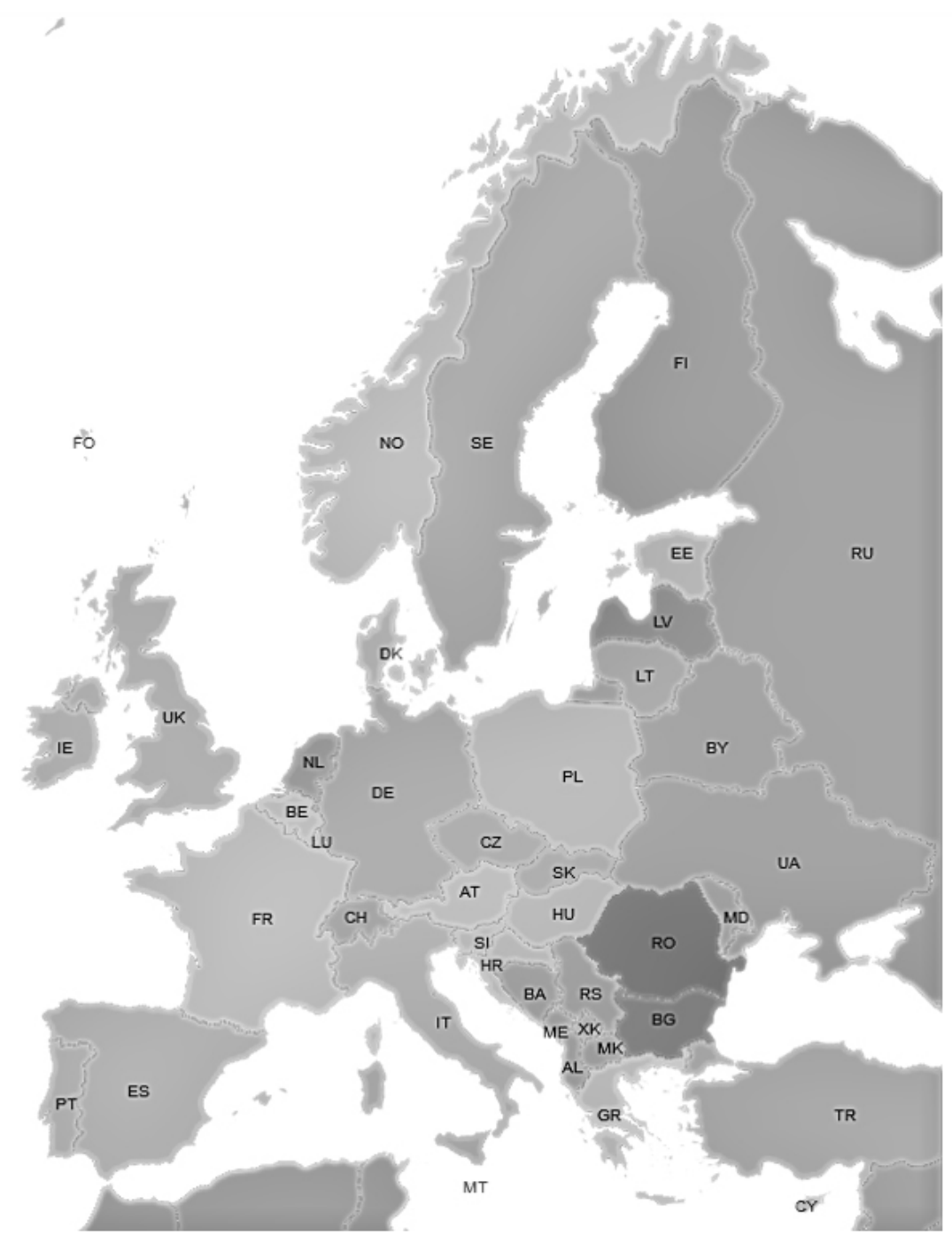

A 15 év feletti lakosság \%-os arányának alakulása, akik naponta legalább egyszer esznek gyümölcsöt (gyümölcslé nélkül) (Proportion (\%) of People Aged 15+ Reporting to Eating Fruits (Excluding J uice) at Least Once a Day)

Forrás (Source): Eurostat, 2014 

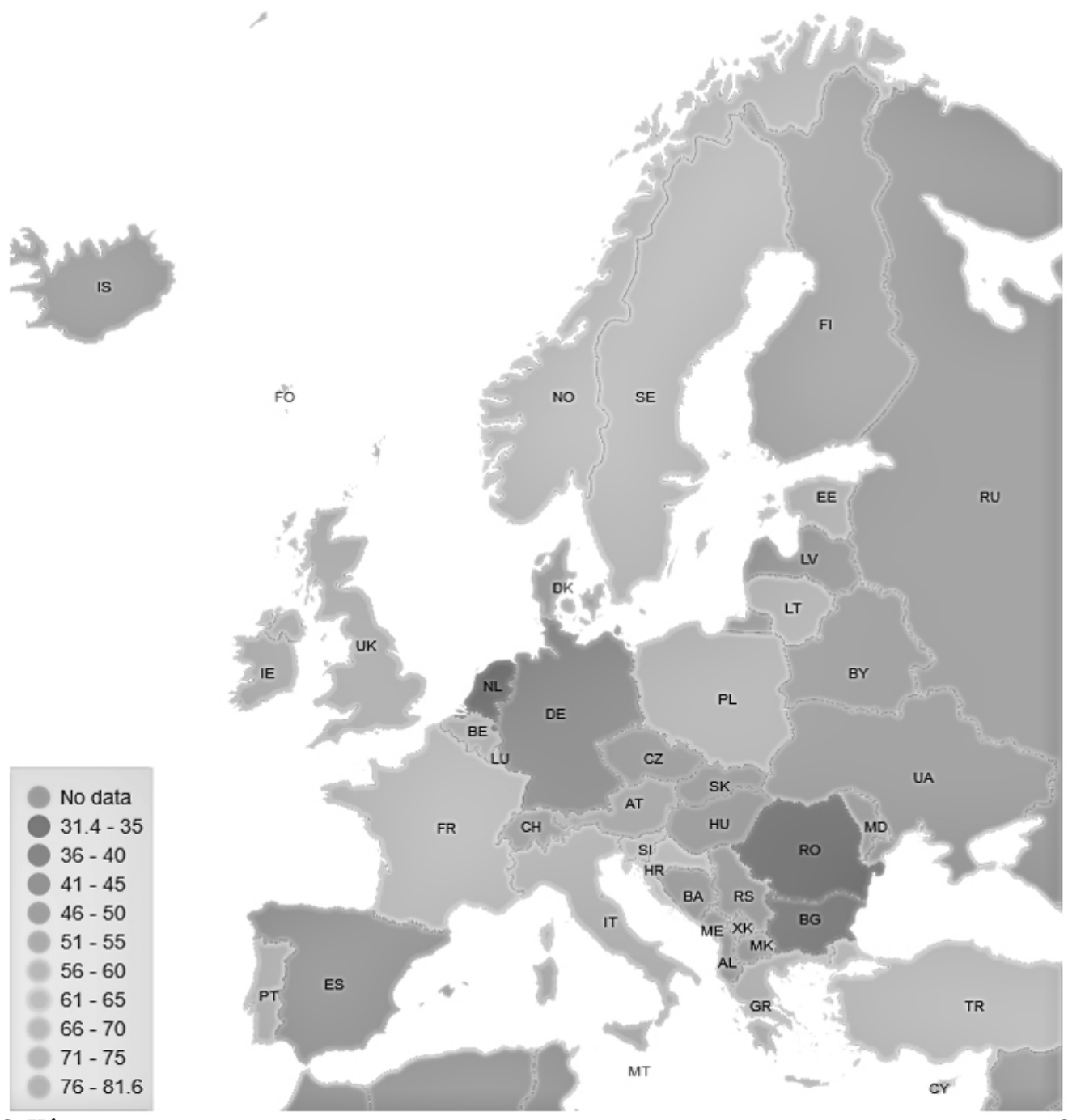

\section{KÉP}

A 15 év feletti lakosság \%-os arányának alakulása, akik naponta legalább egyszer esznek zöldséget (burgonya és zöldséglé nélkül)

(Proportion (\%) of People Aged 15+ Reporting to Eating Vegetables

(Excluding Potatoes and J uice) at Least Once a Day)

Forrás (Source): Eurostat, 2014 


\subsection{Fizikai aktivitás szerepe az egészség megőrzésében - Role of Physical Activity in Health Protection}

Az egyén életmódját jellemző, és az egészségtudatos magatartás legfontosabb faktorai közül a táplálkozáson túl a rendszeres testmozgás, a sportolás fontosságát is számos tanulmány kiemeli (MOSONYI et al., 2013; HERPAINÉ és OLVASZTÓNÉ, 2015; BENDÍKOVÁ, 2017). A rendszeres testmozgás, a fizikai aktivitás szervezetre gyakorolt pozitív hatását, valamint prevencióban és terápiában betöltött szerepét számos hazai és nemzetközi kutatás helyezte vizsgálata középpontjába (DALEY et al. 2006; MÜLLER és RÁCZ, 2011).

Az elhízás, a túlsúly egyik fontos prevenciós eszköze a rendszeres fizikai aktivitás (JANSSEN és LEBLANC, 2010; ÁCS et al., 2011), mely segítheti növelni az energiafelhasználást.

Hazai kutatások eredményei arra hívják fel a figyelmet, hogy az egészséges életmódot befolyásoló két legfontosabb faktor, a testmozgás és táplálkozás területén a szokások, beidegződések megváltoztatása nem könnyü feladat. Hazánkban az élelmiszerfogyasztási szokások változtatása nehezebb, mint a fizikai aktivitásra ösztönzés (SOÓS, KOVÁCS és SZAKÁLY, 2016).

A mérsékelten erőteljes fizikai aktivitás előnyösen hat a serdülők fizikai, szellemi és pszicho-szociális egészségére, mivel segíti az egészséges csontok és izmok építését és fenntartását, csökkenti a depresszió és a szorongás érzését (JANSSEN és LEBLANC, 2010; SINGH et al., 2012).

A felnőtt lakosságnak a WHO ajánlása szerint legalább heti 150 perc mérsékelt intenzitású aerob fizikai aktivitást vagy legalább 75 perc intenzív aerob fizikai aktivitást, illetve ezek kombinációját kellene végezni. Az Európai Unió felnőtt polgárainak kétharmada nem éri el a javasolt fizikai aktivitási szintet. Ezáltal a fizikai inaktivitás évente átlagosan több mint 8 millió, egészségben eltöltött naptól fosztja meg az európai lakosságot (WHO, 2010).

A hazai helyzet is kedvezőtlenül alakul a rendszeres testmozgást vizsgálva, mivel 2014ben csupán minden 9. magyar végzett a WHO ajánlásának megfelelő testmozgást. A felnőtt lakosság keveset mozog: nem gyalogol, nem sportol eleget és sok időt tölt ülve. Hazánk lakosságának 77\%-a volt inaktív 2009-ben, mely adat csak mérsékelt javulást mutat (a lakosság 68\% inaktív) 2013-ra (EUROBAROMÉTER, 2014). Az inaktivitás csökkenésének hátterében állhat az egészségtudatos magatartás terjedése, a szabadidősport infrastruktúrafejlesztése (kondiparkok, felnőtt játszóterek stb.) és központi támogatással megvalósult életmód programok valamint azok marketingkommunikációja.

Szükséges a testmozgásalapú programok kínálatának bővítése, a lakosság számára történő biztosítása, amelyben az egészségvédő-életőrző sportok, a természetben üzhető life-time jellegü sportmozgások dominanciája érvényesül a szervezetre gyakorolt pozitív hatásai miatt (BENDÍKOVÁ, 2017; DOBAY, 2015).

\section{KöVETKEZTETÉSEK ÉS JAVASLATOK - CONCLUSIONS AND SUGGESTIONS}

A más országokban tapasztalt közegészségügyi reformok tanulságait (pl. SWINBURN et al., 2004) adaptálni kellene, mely rámutat arra, hogy a zöldség és gyümölcsfogyasztás növelése, illetve ezeknek az elérhetőségének a biztosítása a lakosság körében fontos. A reformok a testmozgást ösztönző programokat, az egészséges táplálkozás területén a kalóriabevitel csökkentését, a magas rosttartalmú élelmiszerek növelését, valamint a felvilágosító programokat és annak promócióját tartja fontosnak az iskolai és munkahelyi beavatkozási területeken. Igaz, hazánkban is a büférendelet vagy a 37/2014. (IV. 30.) EMMI rendelet bevezetésével (mely a közétkeztetésre vonatkozó táplálkozás-egészségügyi előírásokról szól) történtek pozitív változások a közétkeztetésben, de ez talán még mindig nem elég ahhoz, hogy jelentősebb egészségügyi előnyöket tudjunk elérni.

Egyedül a svédek tudtak arról beszámolni Európában, hogy képesek voltak az elhízás arányát csökkenteni. A stratégiában nem csak a rendszeres testmozgás kapott fontos szerepet, de a táplálkozás is, melyben a zöldségek és gyümölcsök fogyasztásának arányát növel- 
ték (BERGSTRÖM és BLOMQUIST, 2009; SUNDBLOM et al., 2010).

Fontos, hogy támogató környezet legyen a gyümölcs- és zöldségfogyasztás területén. Ez számos olyan beavatkozást tartalmazhat, mint a gyümölcs- és zöldségfélékhez való hozzáférés növelése, állami támogatások a termelésben; az egészséges táplálkozást támogató agrárpolitika (SCHAFER-ELINDER, 2003), hogy ezáltal a lakosság minél szélesebb köre meg tudja vásárolni a zöldség és gyümölcs árukat (WHO, 2001); megfelelő finanszírozást és politikát az iskolák számára; megfelelő iskolai étkezési szolgáltatásokat, ideértve a helyi friss gyümölcsök és zöldségek felhasználásának ösztönzését (NHS, 2002).

\section{5. ÖSSZEFOGLALÁs - SUMMARY}

A gyümölcs- és zöldségfogyasztás és a fizikai aktivitás növelése egy praktikus stratégia valamennyi korosztály számára, hogy megőrizzék egészségüket és a krónikus betegségek kockázatát csökkentsék. Az egészségfejlesztés területén a rendszeres testmozgás és az egészséges táplálkozási szokások kialakítása és megszilárdítása a köznevelési intézményekben - ahol a gyerekek életmódjába beépülhet - hosszú távon eredményezhet egy egészségesebb felnövekvő generációt (HIDVÉGI és BÍRÓ, 2015).

A rendszeres sportolással, fizikai aktivitással az elhízás csökkenthető. Több hazai és nemzetközi kutatás bemutatja azt, hogy a heti többszöri rendszeres testmozgás vagy a fizikai aktivitás egészség-előnnyel jár, illetve a rendszeresen sportoló populációban kevesebb azoknak a száma, akik a BMI index alapján a túlsúlyos vagy az elhízott kategóriába tartoznak (DONNELLY et al., 2013; WIKLUND, 2016; HERPAINÉ et al., 2017). Ezért a népegészségügyi stratégiáknak, a beavatkozási területeknek az egészséges táplálkozáson túl a testmozgást ösztönző programok is nélkülözhetetlen elemei kell, hogy legyenek.

\section{KöSZÖNETNYILVÁNÍTÁs -}

\section{ACKNOWLEDGEMENT}

A publikáció elkészítését a EFOP-3.6.2-162017-00003 számú projekt támogatta. A projekt az Európai Unió támogatásával, az Európai Szociális Alap társfinanszírozásával valósult meg.

\section{IRODALOMJ EGYZÉK - REFERENCES}

37/2014. (IV. 30.) EMMI rendelet a közétkeztetésre vonatkozó táplálkozás-egészségügyi előírásokról. http://njt.hu/cgi_bin/njt_doc. cgi?docid=169011.268150 (Letöltés dátuma: 2018. febr. 20.)

Ács, P. - Hécz, R. - Paár, D. - Stocker, M.: A fittség (m)értéke. A fizikai inaktivitás nemzetgazdasági terhei Magyarországon. Közgazdasági Szemle. 2011. 43 689-708.

Aune, D. - Giovannucci, E. - Boffetta, P. - Fadnes, L. - Keum, N. - Norat, T. - Greenwood, D. - Riboli, E. - Vatten, L. - Tonstad, S.: Fruit and Vegetable Intake and the Risk of Cardiovascular Disease, Total Cancer and All-Cause Mortality - A Systematic Review and Dose-Response Meta-Analysis of Prospective Studies. International Journal of Epidemiology. 2017. 46 (3) 1029-1056. https://doi.org/10.1093/ije/ dyw319

Arai, Y. - Watanabe, S. - Kimira, M. Shimoi, K. - Mochizuki, R. - Kinae, N.: Dietary Intakes of Flavonols, Flavones and Isoflavones By Japanese Women and the Inverse Correlation Between Quercetin Intake and Plasma LDL Cholesterol Concentration. Journal of Nutrition. 2000. 131 (9) 2243-2250. https://doi. org/10.1093/jn/130.9.2243

Bendíková, E.: Theory of Health, Movements and Lifestyle of Human Beings. Debrecen University Press, Debrecen, 2017. 
Bergström, E. - Blomquist, H. K.: Is The Prevalence of Overweight and Obesity Declining Among 4-Year-Old Swedish Children? Acta Paediatrica. 2009. 98 1956-1958. https://doi.org/10.1111/j.16512227.2009.01490.x

Boyle, S. P. - Dobson, V. L. - Duthie, S. J. - Kyle, J. A. M. - Collins, A. R.: Absorption and DNA Protective Effects of Flavonoid Glycosides From an Onion Meal. European Journal of Nutrition. 2000. 39 213-223. https://doi.org/10.1007/ s003940070014

Büfé-rendelet - $A z$ oktatási miniszter 32/2005. (XII. 22.) OM rendelete a nevelési-oktatási intézmények müködéséról szóló 11/1994. (VI.8.) MKM rendelet módosításáról. http:// www.nefmi.gov.hu/letolt/kozokt/ bufeajanlas_05_07_26.pdf (Letöltés dátuma: 2018. febr. 23.)

Daley, A. J. - Copeland, R. J. - Wright, N. P. - Roalfe, A. - Wales, J. K. H.: Exercise Therapy as a Treatment for Psychopathologic Conditions in Obese and Morbidly Obese Adolescents: A Randomized, Controlled Trial. Pediatrics. 2006. 188 (5) 2126-2134. https://doi. org/10.1542/peds.2006-1285

Dernini, S. - Berry, E. M.: Mediterranean Diet: From a Healthy Diet to a Sustainable Dietary Pattern. Frontiers in Nutrition. 2015. 2 15. https://www.frontiersin. org/article/10.3389/fnut.2015.00015 (Letöltés dátuma: 2018.02.23.) https:// doi.org/10.3389/fnut.2015.00015

Dietary Guidelines For Americans 2015-2020: https://health.gov/ dietaryguidelines/2015/guidelines / (Letöltés dátuma: 2018. febr. 23.)

Dobay, B.: Az iskolai sporttanfolyamok motivációs hatása a felnőttkori rekreációs sporttevékenységekre Dél-Szlovákiában. Kompress Kiadó, Komárom, 2015.

Donnelly, J. E. - Honas, J. J. - Smith, B. K. - Mayo, M. S. - Gibson, C. A. Sullivan, D. K.: Aerobic Exercise Alone Results in Clinically Significant Weight Loss for Men and Women: Midwest Exercise Trial 2. Obesity. 2013. 21 (3) E219-E228. https://doi.org/10.1002/ oby. 20145
Dragsted, L. O. - Strube, M. - Larsen, J. C.: Cancer-Protective Factors in Fruits and Vegetables: Biochemical and Biological Background. Pharmacol Toxicol. 1993. 72 116-135. https://doi. org/10.1111/j.1600-0773.1993.tbo1679.x

Erdei, G. - Kovács, V. A. - Bakacs, M. - Martos, É.: Országos Táplálkozás és Tápláltsági Állapot Vizsgálat 2014. I. A magyarfelnőttlakosság tápláltságiállapota. Orvosi Hetilap. 2017. 158 (14) 533-540. https://doi.org/10.1556/650.2017.30700

Eurobarométer, 2014: http://ec.europa. eu/commfrontoffice/publicopinion/ archives/ebs/ebs_412_en.pdf (Letöltés dátuma: 2018. febr. 23.)

Eurostat, 2014: Public Health http:// ec.europa.eu/health/dyna/echi/datatool/ index.cfm?indlist=50 (Letöltés dátuma: 2018. febr. 28.)

Fuchs, V.: Reflections on the Socio-Economic Correlates of Health. Journal of Health Economics. 2004. 23 653-661. https:// doi.org/10.1016/j.jhealeco.2004.04.004

Hartley, L. - Igbinedion, E. - Holmes, J. - Flowers, N. - Thorogood, M. Clarke, A. - Stranges, S. - Hooper, L. - Rees, K.: Increased consumption of Fruit and Vegetables for the Primary Prevention of Cardiovascular Diseases. Cochrane Database of Systematic Reviews. 2013. 4 (6) 55. https://doi. org/10.1002/14651858.CDoo9874

Henter, I. - Mramurácz, É. - Szabó, Zs.: Táplálkozástani és élelmezéstani ismeretek. EKF Líceum Kiadó, Eger, 2013. 106. https://uni-eszterhazy.hu/public/ uploads/taplalkozastani-es-elelmezestaniismeretek_5695949068edc.pdf (Letöltés dátuma: 2018. febr. 27.)

Herpainé, L. J. - Olvasztóné, B. Zs.: Recreational Activites in the Different Kind of Generation in Connection with Physical Activity. Health and Physical Activities in Lifestyle among Children and Youth. 2015. 10-21.

Herpainé, L. J. - Simon, I. Á. - Nábrádi, Zs. - Müller, A.: Családok sportolási szokásainak szocioökonómiai hátterére. Képzés és Gyakorlat: Training And Practice. 2017. 15 (4) 37-52. 
Hidvégi, P. - Bíró, M.: A rekreáció elmélete és módszertana 2.: Egészségfejlesztés. Líceum Kiadó, Eger, 2015.

IFIC, 2007: International Food Information Council Foundation: Food \& Health Survey, Consumer attitudes toward Food, Nutrition \& Health. A Benchmark Survey, 2007. http://ific.org (Letöltés dátuma: 2018. febr. 23.)

Janssen, I. - LeBlanc, A.: Systematic Review of the Health Benefits of Physical activity and Fitness in School-aged children and Youth. International Journal of Behavioral Nutrition and Physical Activity. 2010. 7 (40) https://doi. org/10.1186/1479-5868-7-40

Joshipura, K. J. - Hu, F. B. - Manson, J. E. - Stamper, M. J. - Rimm, E. B. - Speizer, F. E. - Colditz, G. - Ascherio, A. - Rosner, B. Spiegelman, D. - Willett, W. C.: The Effect of Fruit and Vegetable Intake on Risk for Coronary Heart Disease. Annals Internal Medicine. 2001. 134 1106-1114. https://doi.org/10.7326/ooo3-4819-13412-200106190-00010

Jovičić, A. D.: Healthy Eating Habits among the Population of Serbia: Gender and Age Differences. Journal of Health, Population and Nutrition. 2015. 33 (1) 76-84.

Kaplan, G. A.: Social Determinants of Health, 2nd Edition. M Marmot and R Wilkinson (eds). Oxford: Oxford University Press, 2006, ISBN: 9780198565895., International Journal of Epidemiology. 2006. 35 (4) 1111-1112.

Kiss, M. -Szakály, Z. - Soós, M. - Kontor, E.: Az egészségtudatosság megjelenése a magyar lakosság táplálkozási szokásaiban korcsoportonként. Magyar Táplálkozástudományi Társaság XVL. Vándorgyülése, Esztergom, 2016.

KSH, 2017: http://www.ksh.hu/docs/hun/ xstadat/xstadat_eves/i_zhco23a.html (Letöltés dátuma: 2018. febr. 26.)

Le Marchand, L. - Murphy, S. P. Hankin, J. H. - Wilkens, L. R. Kolonel, L. N.: Intake of flavonoids and lung cancer. Journal of the National Cancer Institute. 2000. 92 (2) 154-160. https://doi.org/10.1093/jnci/92.2.154
Liu, R. H.: Health Benefits of Fruit and Vegetables Are from Additive and Synergistic Combinations of Phytochemicals. American Journal Clinical Nutrition. 2003. 78 (3) 517-520. https://doi.org/10.1093/ajcn/78.3.517S

Mackenbach, J. P. - Stirbu, I. - Roskam, A. J. - Schaap, M. M. - Menvielle, G. - Leinsalu, M. - Kunst, A. E.: Socioeconomic Inequalities in Health in 22 European Countries. New England Journal of Medicine. 2008. $\mathbf{3 5 8}$ 2468-2483. https://doi.org/10.1056/ NEJMsao707519

Mosonyi, A. - Könyves, E. - Fodor, I. Müller, A.: Leisure Activities and Travel Habits of College Students in He Light of a Survey. Apstract. 2013. 7 (1) 53-57.

Müller, A. - Rácz, I.: Aerobic és Fitness irányzatok. Pécs Dialóg Campus Kiadó, Budapest, 2011.

Nagy, B. - Nagy-Lőrincz, Zs. - Bakacs, M. - Illés, É. - Sarkadi Nagy, E. Martos, É.: Országos Táplálkozás és Tápláltsági Állapot Vizsgálat - OTÁP 2014.III. A magyar lakosság makroelembevitele. Orvosi Hetilap. 2017. 158 (17) 653-661.

NEFI, 2016: Egészségjelentés, 2016 http://www.egeszseg.hu/szakmai_ oldalak/assets/cikkek/17-05/ egeszsegjelentes-2016.pdf (Letöltés dátuma: 2018. febr. 26.)

NHS, 2002.: The National School Fruit Scheme. Department of Health, UK, London. https://www.nhs.uk/ Livewell/5ADAY/Pages/Schoolscheme. aspx (Letöltés dátuma: 2018. febr. 23.)

Niva, M.: All Foods Affect Health': Understandings of Functional Foods and Healthy Eating Among Health-Oriented Finns. Appetite. 2007. 48 384-393.

OTÁP, 2014: https://www.ogyei.gov.hu/ otap_2014/ (Letöltés dátuma: 2018. febr. 26.)

OECD, 2017: Health at a Glance, 2017 http://www.oecd-ilibrary.org/docserver/ download/8117301e.pdf? expires $=1519636$ 505\&id $=$ id\&accname $=$ guest $\&$ checksum $=$ 91EB5 2 ACo 877 D 63 FC53 EA4 EEEB D56897 (Letöltés dátuma: 2018. febr. 02.) 
Physical Activity Guidelines For Americans, 2008: https://health.gov/ paguidelines/pdf/paguide.pdf (Letöltés dátuma: 2018. febr. 21.)

Polivy, J. - Herman, C. P.: Mental Health and Eating Behaviors: A Bi-Directional Relation. Canadian Journal of Public Health. 2005. 96 (3) 43-46., 49-53.

Popper, R. - Kroll, J. J.: Conducting Sensory Research with Children. Journal of Sensory Studies. 2005. 20 75-87. https://doi.org/10.1111/j.1745459X.2005.00007.x

Povey, R. - Conner, M. - Sparks, P. - James, R. - Shepherd, R.: Interpretations of Healthy and Unhealthy Eating, and Implications for Dietary Change. Health Education Research. 1998. 13 171-183. https://doi.org/10.1093/ her/13.2.171

Rigó, J.: Dietetika. Medicina Könyvkiadó, Budapest, 2007.

Robertson, A. - Tirado, C. - Lobstein, T. - Jermini, M. - Knai, C. - Jensen, J.: Food and Health in Europe: A New Basis for Action. European Series. 2004. 96.

Schafer-Elinder, L.: Public Health Aspects of the EU Common Agricultural Policy. Developments and Recommendations for Change in Four Sectors: Fruit and Vegetables, Dairy, Wine and Tobacco. National Institute of Public Health. 2003.

Schreiberné Molnár, E. - Nagy-Lőrincz, Zs - Nagy, B. - Bakacs, M. - Kis, O. - Sarkadi Nagy, E. - Martos, É.: Országos Táplálkozás és Tápláltsági Állapot Vizsgálat - OTÁP2014. V. A magyar lakosság vitaminbevitele. Orvosi Hetilap. 2017. 158 (33) 1302-1313.

Shepherd, J. - Harden, A. - Rees, R. Brunton, G. - Garcia, J. - Oliver, S. - Oakley, A.: Young People and Healthy Eating: A Systematic Review of Research on Barriers and Facilitators. Health Education Research. 2006. 239-257. https://doi.org/10.1093/her/cyho6o
Singh, A. - Uijtdewillingen, L. - Twisk, J. W. R. - Mechelen, W. V. Chinapaw, M. J. M.: Physical Activity and Performance at School: A Systematic Review of the Literature Including Methodological Quality Assessment. Archives of Pediatrics and Adolescent Medicine. 2012. 166 (1) 49-55. https:// doi.org/10.1001/archpediatrics.2011.716

Soós, M. - Kovács, B. - Szakály, Z.: A viselkedésváltozás szintjei a testtömeg-menedzselés folyamatában élelmiszerfogyasztás és fizikai aktivitás. Táplálkozásmarketing. 2016. 3 (2) 19-27. https://doi.org/10.20494/TM/3/2/2

Story, M. - Neumark-Sztainer, D. - French, S.: Individual and Environmental Influences on Adolescents Eating Behaviors. Journal of the American Dietetic Association. 2002. 102 (3) 40-51. https://doi.org/10.1016/Sooo28223(02)90421-9

Sundblom, E. - Sjöberg, A. - Blank, J. - Lissner, L.: Childhood ObesityRecent Trends in Sweden Including Socioeconomic Differences. Childhood Obesity Prevention. 2010. 448.

Swinburn, B. A. - Caterson, I. - Seidell, J. C., - James, W. P. T.: Diet, nutrition and the prevention of excess weight gain and obesity. Public Health Nutrition. 2004. 7 (1a) 123-146. https://doi. org/10.1079/PHN2003585

Szücs, Zs.: Okostányér - Új Táplálkozási Ajánlás A Hazai Felnőtt Lakosság Számára. Új Diéta. 2016. (2-3) 20-23. http://mdosz. hu/hun/wp-content/uploads/2017/o1/ ud-2016-2-3_final.pdf (Letöltés dátuma: 2018. febr. 20.)

Varga-Hatos, K. - Karner, C.: A lakosság egészségi állapotát befolyásoló tényezők. Egészségügyi Gazdasági Szemle. 2008. 2 25-33.

Vitrai, J. - Bakacs, M. - Varsányi, P.: Hazai egészség-pillanatkép, 2017 Egészségfejlesztés. 2017. 58 (4) 
WHO, 2001. Urban and Peri-Urban Food and Nutrition Action Plan. Elements for Community Action to Promote Social Cohesion and Reduce Inequalities Through Local Production for Local Consumption. World Health Organization. http://apps. who.int/iris/bitstream/10665/108407/1/ E72949.pdf (Letöltés dátuma: 2018. febr. 23.)

WHO, 2002. The World Health Report, 2002. Reducing Risks, promoting healthy life. World Health Organization. http:// www.who.int/whr/2002/en/whro2_ en.pdf?ua=1 (Letöltés dátuma: 2018. febr. 23.)

WHO/FAO, 2003. Diet, Nutrition and the Prevention of Chronic Diseases. Geneva: World Health Organization; 2003. 149. http://apps.who.int/iris/ bitstream/10665/42665/1/WHO_ TRS_916.pdf (Letöltés dátuma: 2018. febr. 23.)
WHO, 2010: Global Recommendations on Physical Activity for Health. http://apps. who.int/iris/bitstream/10665/44399/1/ 9789241599979_eng.pdf (Letöltés dátuma: 2018. febr. 23.)

Wiklund, P.: The Role of Physical Activity and Exercise in Obesity and Weight Management: Time for Critical Appraisal. Journal of Sport and Health Science. 2016. 5 (2) 151-154. https://doi.org/10.1016/j. jshs.2016.04.001

World Cancer Research Fund, American Institute for Cancer Research (2007): Food, Nutrition, and Physical Activity, and the Prevention of Cancer: a Global Perspective. AICR, Washington Dc. https://www.wcrf.org/sites/default/ files/Second-Expert-Report.pdf (Letöltés dátuma: 2018. febr. 23.)

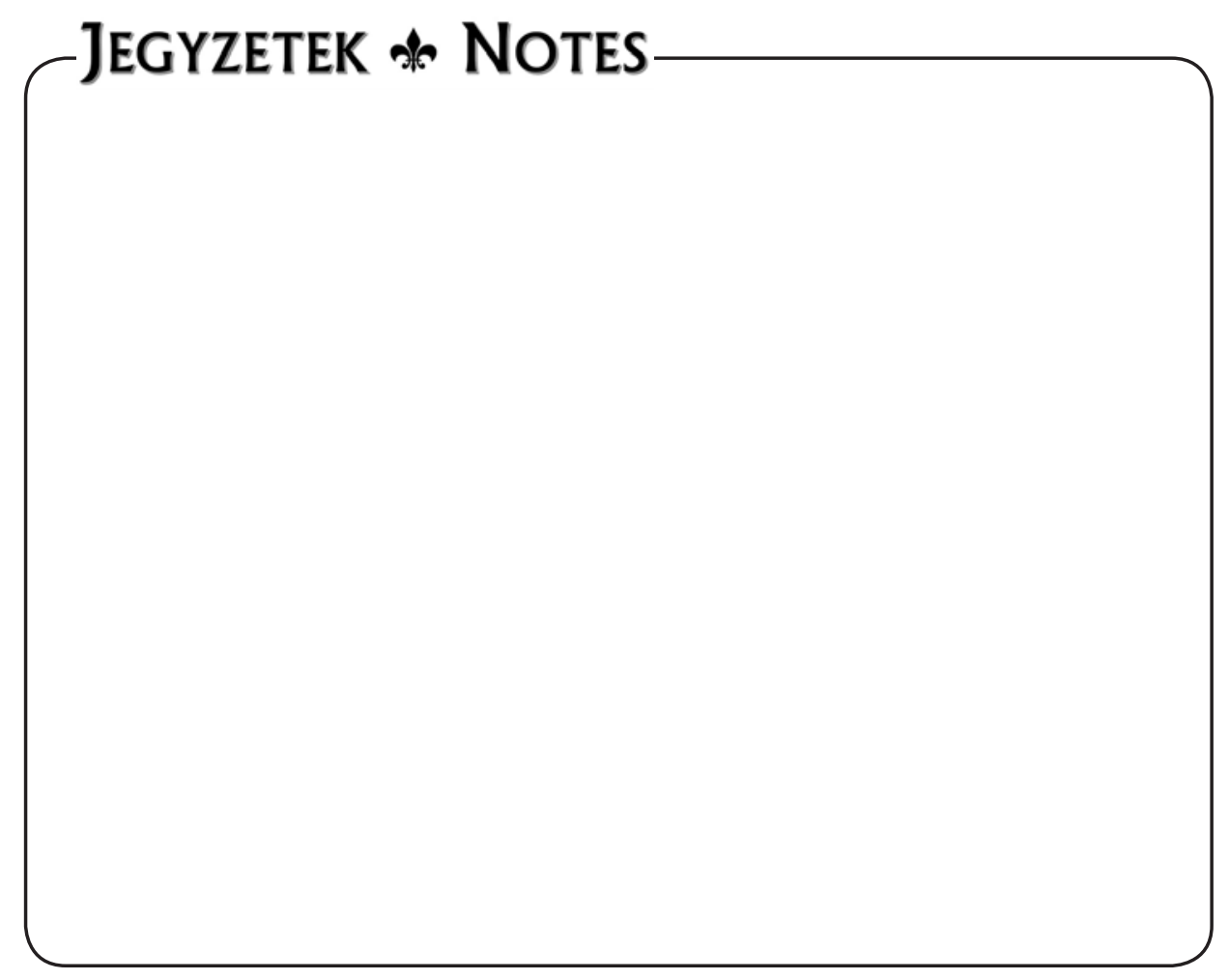




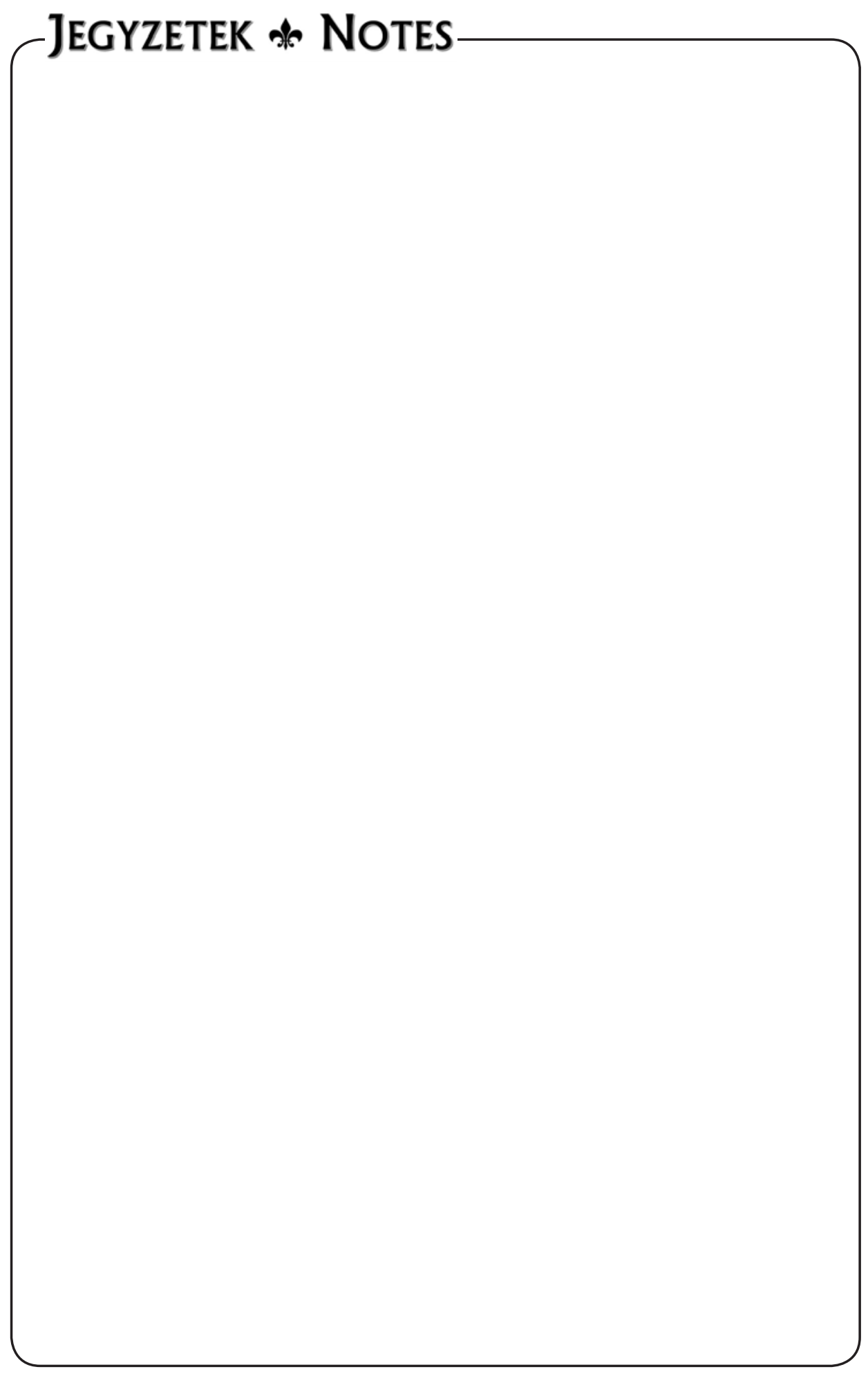

